Wesleyan University

From the SelectedWorks of Richard Adelstein

1992

\title{
Continuity and Change Redux: Market and State in American History
}

Richard Adelstein, Wesleyan University 
Continuity and Change Redux: Market and State in American History

The Governmental Habit Redux: Economic Controls from Colonial Times to the Present by Jonathan R. T. Hughes

Review by: Richard P. Adelstein

Reviews in American History, Vol. 20, No. 1 (Mar., 1992), pp. 1-7

Published by: The Johns Hopkins University Press

Stable URL: http://www.jstor.org/stable/2703259

Accessed: $31 / 05 / 2012$ 12:32

Your use of the JSTOR archive indicates your acceptance of the Terms \& Conditions of Use, available at http://www.jstor.org/page/info/about/policies/terms.jsp

JSTOR is a not-for-profit service that helps scholars, researchers, and students discover, use, and build upon a wide range of content in a trusted digital archive. We use information technology and tools to increase productivity and facilitate new forms of scholarship. For more information about JSTOR, please contact support@ jstor.org. 


\title{
CONTINUITY AND CHANGE REDUX: MARKET AND STATE IN AMERICAN HISTORY
}

\author{
Richard P. Adelstein
}

Jonathan R. T. Hughes. The Governmental Habit Redux: Economic Controls from Colonial Times to the Present. Princeton: Princeton University Press, 1991. xv + 265 pp. Tables, notes, and index. \$29.95.

As the twentieth century draws to a close, Jonathan R. T. Hughes argues in this illuminating and provocative revision of The Governmental Habit (1977), Americans find the great legacy of the nineteenth century, their robust free economy, at a sorry pass indeed. Once a mighty engine of growth and technological innovation, it now lies supine, bound from head to toe by a myriad of government regulations like Gulliver in the land of Lilliput and afflicted for forty years with a "banana-republic fiscal policy" (p. 218), its industries losing their competitive vigor in international markets and its people gradually surrendering their liberties to an increasingly powerful national state. But if the Lilliputians pinned Gulliver to the ground in pursuit of a clearly defined plan, the same cannot be said of the history of government interference in the American marketplace. For Hughes shows the steady accretion of nonmarket controls since 1870, especially at the federal level, to have been a series of piecemeal, uncoordinated responses to specific market outcomes that were seen to be problems of public policy only because influential private interests were able to persuade the government of the moment that they were. The result has been a dysfunctional labyrinth of regulation that, despite the toothless efforts of Jimmy Carter and Ronald Reagan, thwarts our straining economy at every turn, producing neither the distributional equity that systematic planning might offer nor the allocational efficiency that a truly free market could provide.

Hughes's thesis, argued persuasively and at times passionately, is that this was "not only the inevitable outcome of our methods, but that what we wanted was not efficiency but the market interference itself. As economics such a conclusion is at best paradoxical. As history it is an insight into deeply rooted tendencies in American society" (p. 15). Americans have always distrusted the market, and submitted to its disciplines only when it has suited them. "We 
have politicized the economy in favor of special interests since colonial times: it is the All American way" (p. xiii). Like an institutional gene pool, moreover, the ancient customs and forms of control encoded in the English common law and imported by the colonists have largely shaped the development of American regulatory technique to the present day. For his richly detailed and convincing demonstration of these evolutionary continuities, informed by a sharp economic common sense and a sophisticated appreciation of American constitutional theory and history, Hughes has put economic historians in his debt. But there is an irrepressible subtext of change in his story as well, and if Hughes has succeeded in tracing a clear line of descent from Elizabeth's Statute of Artificers to the Nuclear Regulatory Commission, his correspondingly muted account of the three great shifts in our regulatory mood since independence and their effects on both market and state is rather less compelling.

Free markets based on private ownership and easy alienability are England's gift to America, but from the outset, English law and custom also brought close state supervision of these markets. In the English systems of land tenure and labor organization, transplanted intact to the New World, lay the roots of both. Socage tenure guaranteed owners full rights to exploit the land and its resources, and made land a divisible, salable commodity subject only to the power of the state to tax or seize it for nonpayment. Economic liberty and state control existed side by side, with the former predominating. Labor markets saw a similar juxtaposition, though here control held the upper hand. White workers were typically indentured servants, and while masters could freely buy and sell their services for the life of the labor contract, compulsory labor at governmentally fixed wages, meant to instill discipline in workers treated as social inferiors, was the norm. Colonial America "was no hotbed of laissez-faire" but "a place where men with money thrived by making the poor work" (p. 37). Business too was closely regulated by entry and price controls, taxes, subsidies, and legally enforced quality control, all strongly influenced by English doctrine. But a native taste for order was at work as well, and though the colonists chafed under British regulations and taxes, similar controls quickly emerged in the new republic.

It was, Hughes argues, the opening of the West that liberated the market, even as it drew on the older tradition of control, and heralded the first great change in the culture of regulation in the United States. Socage tenure was easily adapted to the new regime of self-government; the ordinances of 1785 and 1787 secured the rights of individuals in land they had acquired from elected governments and allowed the price mechanism to determine the details of occupancy while government controlled only the broad outlines of distribution. The labor needed to settle the land was largely supplied in mar- 
kets as well, as voracious American demand and a rapid growth of population in preindustrial Europe combined to produce a wave of immigration. And though government was deeply involved in the construction of roads, canals, and railways by specially chartered private corporations, by 1850 an indigenous movement to open the privilege of incorporation to businesses of all kinds had gained momentum everywhere. As Hughes observes, the unseemly competition between the states for the favor of the new corporations was "an excellent example of manipulation of state government for the benefit of private interests" (p. 81). But it was also an acknowledgment that competitive markets were the best way to determine how businesses ought to be organized.

Hughes has relatively little to say about the reasons for this general relaxation of controls and the concomitant ascendancy of markets in the antebellum period. He relies instead on Lord Bryce's view, expressed in 1888, that it reflected the common man's simple desire to be left alone and his "commonsense notion that everybody knows his own business best, that individual enterprise . . . will 'run America' better than the best government can do" (pp. 118-19). But Hughes is more forthcoming about why the second great shift in the people's attitude toward state intervention, the reaction manifested between the Panic of 1873 and the First World War that he calls the "revulsion against the free market" (p. 92), took place when it did. "Whenever important sectors of the body politic begin to lose advantages formerly available from given lines of endeavor, agitation for nonmarket control appears to preserve or restore the situation" (p. 95). The seeds of reaction, sown in the free-market policies of the 1830s and 1840s, blossomed as the frontier and the opportunities for individual initiative it created began to close. Though the land itself had been distributed in generally egalitarian ways, the accidents of location of oil and mineral deposits whose value could not have been foreseen now created enormous disparities in the wealth the land produced. The attempt to open the opportunities of incorporation to the many now gave rise to giant firms owned by fabulously rich men that robbed thousands of their economic autonomy, just as a new wave of immigration driven by the demand for labor in the factories brought increased competition and lower wages. Laissez-faire, once the servant of the interests of the common settler, now served only those few with access to resources from the remaining public lands, the rising industrialists and financiers, and the impoverished laborers pouring from the boats.

The opening salvo was Munn v. Illinois (1877), a decision Hughes perceptively sees not as vesting new powers of regulation in the states, but rather as extending the reach of the ancient police power to any business, as Chief Justice Waite put it, "clothed in the public interest." But given that the rail- 
roads, the target of the Granger Laws litigated in Munn, were indisputably instruments of interstate commerce, it was inevitable that this state regulatory authority would soon be transferred to the federal government instead. With the creation in 1887 of a federal Interstate Commerce Commission to keep rates on all common carriers "just and reasonable," common law forms of control imported to the colonies in the seventeenth century were refitted for action in the twentieth, and since the carriers themselves were the chief sources of the information and expertise needed by the Commission, the regulated quickly captured control of the regulators, a pattern that has persisted to the present. But if the relatively limited scope and close regulation of the ICC are simply an extension of older technique, the antitrust laws, as Hughes sees them, are something new, an attempt at more general control that leaves room for the price mechanism to operate within limits but makes government the permanent overseer of a market in which competition is played out through continuous innovation in business strategy and behavior. The result, he suggests, is a continuous resetting of the limits as, in the name of protecting competition, government places increasingly complex, numerous, and inconsistent controls on the means firms may adopt to compete.

Hughes's treatment of antitrust is puzzling. He is surely right to say that much of modern policy has been based on the view that competition cannot survive unless it is protected from market forces but that, insofar as competition may lead to monopoly, too much of it is also bad, and that in pursuing this contradictory logic, the government has often meddled in the market to protect existing, inefficient competitors rather than the creative destruction of competition itself. But in his pique at this crimping of competition, he has overlooked the law's vindication of the market process against another plausible and principled interpretation of the Sherman Act that would have posed a far greater threat to it than this. Despite what he sees as the irrationality of their position, Hughes acknowledges that "some of the moving spirits of the Sherman Act knew precisely what they doing; they were attempting to rein in the power of large business organizations in the interests of the more numerous, and politically effective, small businesses of the country" (p. 114). For these Jeffersonian spirits, antitrust was a matter of power, not efficiency, of preserving the moral and political advantages of small scale organization against the apparently inexorable efficiencies of bigness. Their position is "irrational" only to the extent that, as Hughes seems inappositely to assume, all human values can be conflated to the simple maximization of material wealth. But after 1886, when the Supreme Court granted corporations the same constitutional rights against the state's regulatory efforts as living men and women enjoyed, the close control of corporate growth essential to this alternative vision of antitrust was precluded. By 1911, the Court had drawn 
the necessary conclusions; the "rule of reason" it appended to the Sherman Act explicitly accepted large scale organization and the economic power that accompanies it where they had been achieved without unfair or abusive tactics in the market, an endorsement of the competitive process that has not since been challenged in Congress or the courts. Americans, as Louis Brandeis sadly observed years later, had shown that they hated monopoly but loved bigness.

Why? Hughes does not say, though again Lord Bryce offers a clue. Europeans saw the state as a great moral power, "the totality of wisdom and conscience and force of the people, yet greater than the sum of the individuals who compose the people." To Americans, however, the state "seems actually less than the individuals who live under it. The people . . . inspire respect or awe, the organism is ignored." The state "has no more conscience, or moral mission, or titie to awe and respect, than a commercial company for working a railroad or a mine" (p. 118). But as Frank Tariello has argued in The Reconstruction of American Political Ideology, 1865-1917 (1982), precisely this distinction was eroded during these years. First among the intellectuals, but soon throughout the culture, the individualistic political ontology that had dominated the period between the Revolution and the Civil War was replaced by a democratic collectivism that, like the European model that inspired it, saw the state (or society) literally as an organism, with needs and interests of its own, distinct from those of the individuals who comprised it and superior to them in public life. Superimposed on Hughes's own history, moreover, this insight suggests an ideological basis for both the attitudinal shift toward the market after 1787 and the developing reaction against it in the years before 1917. If the commitment to the market was the mirror in economic affairs of the political individualism of the early republic, the increasing taste for regulation in "the public interest" after 1870 equally reflected the ascendancy of the new organic collectivism. The public interest to which the Munn Court appealed in 1877 was still a vague, controversial ideal. But by World War I, Americans had become accustomed to submerging their own interests in those of large organizations pursuing collective purposes through rational management and individual discipline, be they sovereign corporations seeking profit or a reified national state seeking the common good.

All of this would culminate in the war economy, nationalist fervor and social coercion of 1917-18. World War I marks the beginning of a third, rather more complex shift in American regulatory culture. The success of direct, pervasive controls in organizing the nation's response to the emergency smoothed the way to peacetime controls directed toward more mundane ends and, as William Leuchtenburg and Ellis Hawley have shown, the wartime experience deeply colored the New Deal's approach to the depression. 
But as Hughes aptly notes, as natural as it must have seemed to its authors, Roosevelt's strategy was the wrong medicine at the wrong time. Two hundred years of regulatory policy had assumed an expanding economy in need of restraint to curb its excesses, but a "stagnating economy that had to be motivated into life by government action was something strange" (p. 143). Tradition pointed toward direct control; purposeful deficit spending was the prescription only of heretics and cranks. So the New Dealers "did not try what would work; they tried what would be accepted" (p. 145). Recounting their small successes and larger failures, Hughes applauds their efforts and the humane impulses that moved them, even as he makes clear in his excellent discussion of the Supreme Court's reconstruction of the commerce clause between 1937 and 1942 that what they tried was not accepted so easily as that.

It took a second world war to prove the heretics right. But by the time the idea that aggregate economic activity could and should be controlled by the federal government was institutionalized in the Employment Act of 1946, Keynesian policy could only be applied to an economy laced with central controls, burdened by a previously unimaginable expenditure on arms, and called time and again by the state to war. Hughes is correct in calling the state's assumption of responsibility for maintaining employment and growth a "revolution" (p. 180), though he seems not to appreciate the unrealized potential for a still greater revolution in the Keynesian system's general reliance on the price mechanism and oblique, attenuated forms of central control; like the ordinances of the 1780s, it too would have put the government in control of only the broadest outlines of economic activity and left the details to the market. But the political realities of the years since World War II have made this impossible, and Hughes's best pages are given to a sharply perceptive, angry analysis of the perverse distortions of both Keynes's own vision and the American political economy brought about by military Keynesianism. An almost continuous state of war since 1940 has extended the reach of the federal government's taxing power and radically enlarged its spending and debt in a vicious circle. "Government expenditure is no longer based upon established need; instead, the size of GNP establishes the need for government expenditure to funnel the river of taxes back into the private economy" (p. 192), largely on the purchase of arms. The result has been a globe "littered with corpses killed daily by American weapons" (p. 192) and a people whose "whole conception of the individual's place in the social order has been changed, with increasing emphasis upon individual sacrifice to the collectivity" (p. 222).

The Governmental Habit Redux is not without flaws, principal among them its reluctance to search out the intellectual roots of the changes as well as the continuities in the economic and institutional history it tells so well. But to 
fault a work as rich and illuminating as this too strongly for what it does not contain would be churlish. For those who would understand how the revolutionary promise of 1787 has become the deeply troubled reality of today, this book is an excellent place to start.

Richard P. Adelstein, Department of Economics and College of Social Studies, Wesleyan University, is the author of "The Nation as an Economic Unit': Keynes, Roosevelt and the Managerial Ideal," Journal of American History (June 1991): $160-87$. 